\title{
Nicole Torka*
}

\section{Atypical Employment Relationships and Commitment: Wishful Thinking or HR Challenge? ${ }^{* *}$}

Nowadays, simultaneously maintaining flexible working practices and commitment is an important topic for HR managers since they both can contribute to organisational success. However, many HRM researchers and practitioners are unsure whether these can go together as job security is often seen as a necessary condition for commitment. Since relatively little research has yet been completed, this article contributes to this discussion. The aim of this article is to explain how flexible workers can be committed. Since knowledge on the matter is very limited, it was decided to conduct an exploratory, qualitative study, observing and listening to welders and fitters in two Dutch companies.

The results show that there are more congruencies than differences in terms of commitment between the two groups of workers (typical and atypical). Moreover, the findings also indicate that the commitment of atypical workers depends on a whole range of Human Resource Management choices. HRM for these workers does not begin and end with choices made about human resource flows and specific contract policies. Therefore, an active approach to the whole HRM territory (work systems, rewards, human resource flow, and employee influence) would seem desirable. It was found that all employees want employers to listen to their views regarding policy choices that affect them personally.

\section{Key words: Atypical Employment Relationships, Commitment,} HR Policies for Atypical Workers

* Nicole Torka, University of Twente, Faculty Business, Public Administration and Technology, Department HRM, P.O. Box 217, 7500 AE Enschede, The Netherlands, Phone: 0031-53-4893487. E-Mail: n.torka@utwente.nl.

** Article received: March 20, 2004

Revised version accepted after double blind review: April 30, 2004. 


\section{Introduction}

"IBM has halved its number of direct employees from 440.000 to 225.000 worldwide but we still have the same overall number of jobs as before, around 500.000. We have just shifted their status. The group will never go back to full employment in any way. It got its fingers too badly burned in the 1980s" (Peter Hagger, Business Director Global Services in Purcell/Purcell 1998).

Also, statistical evidence on a larger scale seems to support the changes in human resource flow policies and more specific strategic decisions concerning employment relationship policies as reflected in the comment above. In the European Union, 42 million people (27 per cent of the total working population) have so-called atypical employment relationships (CIETT 2000): non-permanent or temporary contracts, freelance contracts, and temping relationships. The last category refers to contractual triangles a 'ménage à trois' between one employee and two employers - such as temporary work through agencies (TWA), personnel on loan, and labour pools. In terms of atypical or flexible work rankings, the Netherlands - the country in which the current research was completed - occupies fourth place in the European Union: only surpassed by Portugal (49.7\%), Spain (47.7\%), Italy (36\%). More than 31 per cent of the Dutch working population have atypical employment relationships: 3.3 per cent do agency work, 14.4 per cent have non-permanent contracts, and 13.8 per cent work as freelancers. Only in the United Kingdom do more people work through agencies than in the Netherlands (3.8\% c.f. $3.3 \%$ ) (Randstad 2004). Therefore it is not surprising that one of the sessions of the third international HRM conference Innovating HRM?' organised by the Dutch HRM Network in 2003 was devoted to 'Innovating the employment relationship'.

Atypical employment relationships imply less job security for employees. Less discussed is the extreme challenge that flexible labour places on the HR function. Many HRM researchers and practitioners believe that increasing labour flexibility not only decreases labour costs, but also reduces HR managers' (and companies') responsibilities since temp agencies appear to reduce the time that has to be invested in recruitment, and rewards. Here, it is argued that these assumptions, and not only from a legal point of view - such as the forthcoming European directive on private agency work, are open to question.

The concept of organisational commitment lies at the heart of any analysis of HRM. Indeed, the whole rationale for introducing HRM policies is to increase levels of commitment so that other positive outcomes can ensue (Guest 1998: 42)

Establishing and maintaining employee commitment is vital to organisational effectiveness (Mellor et al. 2001: 171) as it affects critical behaviours such as performance, absenteeism, and creativity (e.g. Becker et al. 1996, Meyer et al. 1989). Therefore many, including myself, believe that employers would like all workers to share such commitment-associated behaviours. Therefore, one of the most important questions for HR managers should be how can they simultaneously maintain flexible working practices and commitment. There is very little research on contract vs. commitment matters, and the results that are available are contradictory. Some researchers found no differences in the commitment of typical and atypical workers, while others did. So, it would seem, atypical workers are not necessarily less committed than typical 
workers. That is, flexible workers can build up commitment towards a 'nonpermanent employer'. The conflicting results are not the only unsolved mystery in research on the contract-commitment relationship. As in 'pure' flexible labour and commitment research, knowledge establishment tends to be restricted to the search for supposed cause-and-effect relationships. Conspicuously still missing is the insider's perspective - the atypical workers' voices (Kessler et al. 1999: 6): their explanations for their commitment, or lack thereof. Since good HRM practices, ones that contribute to organisational success, are notonly strategically, but also employee-oriented (Beer et al. 1984), an approach that considers workers' views would appear appropriate. Thus, it seems logical to ask:

\section{Which HRM policies explain the (non-) commitment of atypical workers?}

The aim of this article is to explain how commitment can be derived, maintained, and/or destroyed within these workers. Since we are interested in the atypical workers' perspective, an exploratory, qualitative study was seen as appropriate.

This article is structured as follows. Firstly, the theoretical background is presented. 'Traditional' conceptualisations of employee commitment will be discussed, followed by an overview of the assumptions and research on contract relationships and commitment. Secondly, the research approach is described, followed by the findings of the research. Finally, the implications for future contract - commitment research and company policy are outlined.

\section{Theoretical background}

\section{Employee commitment}

One needs to examine how commitment is conceptualised before developing the qualitative pilot study moet zijn 'a' qualitative pilot study. We should bear in mind that only very few researchers have asked subjects directly, or even indirectly, for their perceptions and definitions of commitment (Reichers 1985). Evidence from the employees' perspective is thus lacking but, from the limited research reported, we have some indications that employees' definitions differ to those of researchers. Randall et al. (1990), and Singh and Vinnicombe (2000), conclude as a result of their qualitative studies that a reconceptualisation of commitment appears necessary. Therefore, in the current research, 'traditional' commitment theory has been used merely as an initial sensitising concept (Blumer 1954).

In management literature, all the popular commitment definitions have two subconstructs in common: (1) commitment is a binding force - a psychological state or attitude - that (2) gives direction to behaviour (Meyer/Herscovitch 2001). The most important outcome of commitment is the maintenance of the relationship with the commitment object. Differences among definitions can also be identified. Some definitions relate commitment to the organisation as a whole (e.g. Porter et al. 1974); others focus on less abstract elements of 'organisational life' (e.g. Becker/Billings 1993). One can ask whether commitment towards the organisation as a whole is the only work-related, or the most important, focus of employee commitment. The answer has to be no: additional foci of work-related commitment clearly exist. A growing number of academics do acknowledge that employees can have different work-related com- 
mitments, such as commitment to the work, the job, the career, the occupation, their colleagues, supervisors, teams, and the department. Thus, one should achieve a better understanding of employee commitment by considering the various foci: "commitment is not an all or nothing affair" (Coopey/Hartley 1993: 21). Empirical research supports this view (e.g. Gallie/White 1993, Yoon et al. 1994). Recently, Meyer and Herscovitch (2001) introduced an entity-behaviour distinction: to what - behaviour or entity - is the employee committed? They suggest that when commitment is considered to be directed towards an entity then the behavioural consequences are often implied rather than stated explicitly. Similarly, when commitment is considered to be a course of action, the entity to which that behaviour is relevant can often be inferred even when it is not stated explicitly.

Differences in the several definitions also tend to involve the base or origin of the 'stabilising force'. Several authors treat commitment as a multidimensional construct: meaning that commitment can be attributed to different bases or origins. Allen and Meyer (1990) developed a three-component model of employee commitment, and their resulting questionnaire is the most frequently tested and supported threecomponent measurement of commitment. They discriminate three bases, or origins, of commitment (affective, normative, and continuance commitment). In the current research, the term 'calculative' is preferred to 'continuance' commitment because calculation better indicates the rationale of the underlying cost-benefit analysis, and has less behavioural- or outcome- related associations. In order to explain the concept of bases, an ordinary, and for most of us a well-known, example is offered: why do we stay with our partner? Because we are in love (affective), would be seen nowadays as the most romantic and socially desirable answer. But is it the most realistic and only possible answer? At best, after the 'love is blind' period, our rosy view will be replaced by a more realistic one: we discover the small, or not so small, shortcomings of our mate. So why do we continue the relationship? Some of us stay because we feel obliged to do so (normative): "you shall not divorce" is such a state of mind of moral responsibility. It is also possible that we stay as a result of a cost-benefit analysis. One can be calculatively tied to a partner for two distinct reasons. Firstly, because of a desire to retain the rewards or extension of investments (the high sacrifices dimension). For example, you bought a house together (financial side bet) or would lose prestige through separation (emotional side bet). Secondly, you could stay because of a perceived lack of alternatives (the few alternatives dimension); in the most positive case this could be seen as there is no better partner currently available.

To sum up, in an industrial setting: in terms of traditional commitment theory, employees can be committed through affective bonding, normative conformity, and/or rational choice (Coopey 1995).

Thus, since commitment theory is used in this research as a sensitising concept, one has to be alert for the several foci and bases of commitment that may distinguish one worker from another. 


\section{Assumptions and research on the contract-commitment relationship}

A substantial number of HRM researchers are convinced that atypical employment relationships cannot be advantageous for employee commitment (for example Atkinson/Meager 1986; Baruch 1998; Rousseau 1995). This is not surprising since employee commitment is seen as a 'what comes around goes around' attitude. In other words: why should flexible workers build up any commitment since the company is not willing to meet an important part of the deal, i.e. job security? Furthermore, research suggests that many flexible workers have poorer working conditions than typical workers (e.g. Goudswaard/Andries 2002). Since all work-related HR policies (flow policies, work systems, rewards, and employee influence) are antecedents of commitment (see, for example, Morris et al. 1993), it seems not illogical to suggest that such atypical workers will be less committed - but is this always true? And what happens if companies offer atypical workers the same circumstances apart from the employment relationship?

There is little empirical knowledge about this matter, and the research results that are available are contradictory. Pearce (1993), and Allegro and Van Breukelen (2000), found no differences in commitment between typical and atypical workers. Jacobsen (2000), Millward and Hopkins (1998), Van Dyne and Ang (1998), and Steijn (2000) did find differences: atypical workers did seem to be less committed than typical employees. However, there are further issues with these studies. With the exception of Jacobsen (2000), researchers have excluded the calculative component from their research. Researchers in the field mainly focus on affective commitment, and therefore overstress the importance of this base. For example, it has been found that not only affective, but also normative and calculative, commitment towards an occupation correlates negatively with an intention to leave the profession (Meyer et al. 1993), and therefore the different bases can reinforce each other.

Furthermore, the preferred focus tends to overstress commitment to the abstract organisation. Only Allegro and Van Breukelen (2000), and Millward and Hopkins (1998), chose less abstract foci: respectively the department, and the job. According to both theory and research, commitment can travel upwards, and this is another reason why researchers should be open to a multifocal approach. Many of the demanded commitment-associated behaviours, such as performance, seem to have a stronger relationship with the jobs people do, than with the organisation within which they perform the job (Shore/Martin 1989).

To sum up, many questions on the contract-commitment relationship are not yet answered, and knowledge on the subject is very limited. Furthermore, what type of knowledge do we have about the research topic: only some findings on the distribution of typical and atypical workers' commitment. What is needed, as was argued in the introduction, is a look behind these numbers, asking atypical workers themselves how they see their commitment and trying to understand the mechanisms that affect the attitudes of atypical workers. For another, not unimportant, reason, an exploratory, qualitative approach also seems appropriate. Most research on commitment has been carried out at the 'organisational level', and we know relatively little about bases of less abstract commitments such as towards the department, colleagues, and work. 
An in-depth method seems even more relevant if we listen to the arguments of other researchers since the operationalisations of the concept of commitment have stood still for almost thirty years. Commitment research has thus been based on traditional, 'life time employment', models and it is not clear whether results and/or conceptualisations from such research are transferable to less typical workers (Gallagher/McLean Parks 2001, Gallagher/Sverke 2000). Overall, therefore, there seem reasons enough to adopt an 'unconventional' approach.

\section{Research method}

As relatively little is known about the contract-commitment relationship in general, and the voices of employees in flexible labour and commitment research is largely missing, a qualitative approach was adopted to elicit workers' perceptions of HRM policies and commitment. The research was carried out in two Dutch metal companies. The metal industry, and workers as the research domain, were chosen for two reasons. Firstly, because of the significant amount of flexible labour in the Dutch metal industry: more than 20 per cent of employees in this industry have atypical contracts. The reason being that many firms in this industry are susceptible to market fluctuations and, further, the industry still recalls the trauma of the mass redundancies which took place in the 1980s. Secondly, only a few studies "have entered the realm of shop floor life" (Geary 1992: 38). More specifically, the knowledge of blue-collar perceptions of commitment is very scarce.

\section{Research techniques}

For this study, different methods were used: observations, informal conversations, and semi-structured interviews. To achieve the overall aim of the research, all these techniques are important. Firstly, the observations and informal conversations are discussed, i.e walking and talking the floor. All the things seen and heard from all levels of employees, thus also supervisors and managers, were incorporated. This serves as supporting and explaining information. Several weeks were spent in both companies. In Company 1, during the first two weeks, the 'methodology' was restricted to such unstructured methods and thus was open to new and relevant information. There was only one fixed item - the research object. Why was such an approach chosen? Firstly, it was a matter of acclimatisation given the unfamiliarity with an industrial, blue-collar environment. Furthermore, it was important that none of the possible antecedents of the workers' commitment were overlooked, and this initial experience was an important guide in constructing the interview protocol.

\section{Semi-structured interviews}

Using semi-structured interviews one can describe the workers' perspectives about HRM policies and commitment in a more structured way. The interview protocol not only consists of questions about commitment, but also has questions about personal work-related and non-work-related issues, including HRM practices such as work systems, rewards, flow policies, and employee influence. In terms of commitment, five general questions were posed: 
1. What does commitment mean to you?

2. What does commitment towards your daily work mean to you?

3. What does commitment towards your colleagues mean to you?

4. What does commitment towards your department mean to you?

5. What does commitment towards (name of the company) mean to you?

With question 1, an attempt was made to identify the foci of commitment: which foci do the participants distinguish? The answers to question 1 would determine the appropriate foci for the more detailed investigation (questions $2-5$ ). During the unstructured weeks in Company 1, it was found from the workers that their work, their colleagues, the department, and the organisation as a whole, were the most likely objects of their commitment. Therefore, for these foci, it was attempted to uncover the bases of participants commitment or lack thereof: do they refer to the commonly mentioned theoretical origins, and if so how, or do their meanings differ to the commitment origins defined earlier?

In total, 54 semi-structured interviews with low and medium skilled fitters and welders in the two Dutch medium-sized metal companies were completed. Both companies employed between 130 and 170 employees. The interviews varied in length from forty-five minutes to three hours. All respondents were male and aged between 18 and 60. Twenty-two respondents had typical employment relationships, and 32 atypical contracts (see Table 1). The atypical workers duration of stay with the company in question varied between three months and ten years (but not continuously in the latter case).

Table 1: Atypical employment relationships and number of atypical workers in each category

\begin{tabular}{|l|c|}
\hline Atypical employment relationships & Number \\
\hline Non-permanent contract with the company & 6 \\
Agency workers & 24 \\
Permanent contract with other company & 2 \\
(no agency) & $\overline{32}$ (total number of atypical workers) \\
\hline
\end{tabular}

\section{Data analysis}

As noted earlier, the initial research preconception, or sensitising concept, consists of different bases (affective, normative, and calculative), and foci. If possible, the answers to question 1 were attributed to one or more foci, and the answers to questions 2-5 attributed to the base categories. Answers that did not fit the 'traditional' bases and/or predetermined foci were put in a 'supplementary' category: these are the participants' additions to the initial set of 'possibilities'. Further, for questions 2-5, the workers were asked how strong their commitment was, according to their own definition. Three answer categories were allowed: 1) committed, 2) fairly committed, and 3) hardly or not at all committed. To evaluate the quality of the research results, two techniques were used: multiple peer debriefing (Guba/Lincoln 1992) and multiple member check (Douglas 1976). 
Finally, it is important to note that a cross-case analysis was carried out with the findings from the two companies compared since the companies have some striking similarities which made this possible. Firstly, the companies share one personnel manager. Secondly, the HRM policies on work systems, rewards, human resource flows, and employee influence are quite similar, although there were a few differences which could affect commitment as will be discussed later. Thirdly, they exchange workers since their products having different seasonal peaks (winter and summer respectively). Fourthly, both are so-called original equipment manufacturers: they build recognisable final products. Finally, the job content in both companies is quite similar: fitters assemble the whole product from beginning to end, and welders manufacture the necessary components.

\section{Findings}

\section{Question 1: What does commitment means to you?}

A minority of workers linked commitment to foci in line with commitment theory (22 of 54) ${ }^{1}$. These answers are first discussed. Two examples of the responses are as follows:

I am not very much committed to my work (commitment The reason for my low commitment is the kind of work I do. This work is too coarse for me (antecedent of commitment). My low commitment affects the way I work. For example: I stuck this sticker (shows me) in the wrong place because I do not care that much. If I was more committed I would work more neatly (outcome of commitment). But I am committed towards my colleagues (commitment object: colleagues). I help them whenever I can (outcome of commitment).

Sometimes I am committed, because I think that (name of company) is good in comparison with other companies. I have to give something back. I get annoyed about people who bullshit with each other. It hurts me if I see that kind of behaviour, (name of company) does not pay for that. You have to show that you're worth the money you get.

Looking at the first quote, one should note that this man (trainee on a non-permanent contract) distinguishes different objects of commitment: work and colleagues. Such multi-foci answers were common, and the same was found with questions 2-5: many men named several motives. Furthermore, he blames his low work commitment on the task content (work systems), and explains the consequences of (non-)commitment through behavioural examples. Concerning the second quote, the worker's motive is of a normative nature: employees should exhibit and refrain from certain behaviours because it is the right and normal thing to do (Wiener 1982). What is eye-catching, and that counts for all findings, many workers' explanations on commitment are behavioural oriented. This counts especially for normative definitions: without mentioning them directely, most workers describe norms and values through courses of action.

The four most mentioned foci of employee commitment were: the work $(31 \%)$, their colleagues $(17 \%)$, the company $(13 \%)$, and the department $(6 \%)$. Four of the seven respondents who mentioned 'the organisation' were in fact expressing commitment towards an external organisation. They (also) felt commitment towards another

Six men $(9 \%)$ did not feel able to answer this question. 
work organisation (temp agency, family company, and 'regular' employer). To summarise, the workers seem to connect their own commitment to tangible objects (work, colleagues) rather than to the abstract 'surroundings' (department, company). This is not surprising, since it is recognised that the function-level is an antecedent of commitment towards the organisation as a whole: in general, employees with a lower hierarchical position have less organisational commitment than employees with a higher position (e.g. Welsch/LaVan, 1981). The workers themselves support this outcome: in a technical, manual job you have little to do with the ins and outs of the department and the organisation as a whole. However, their 'status' is not the only, or the most important, reason for their limited department and organisational commitment. According to them, the personnel policies are also responsible: commitment by the employer is lacking. Many espondents (26 of 54) associated commitment not only with their own commitment: they should themselves be an object of employer commitment: expressed by reasonable employee influence over policy and through their treatment in everyday situations. The former serves as a precondition for the latter. An example of 'improper' behaviour:

The production manager does not see us. He is always in a hurry and does not greet us. He never asks how things are going. That's bad.

The next quote expresses inappropriate participation practices from the standpoint of the worker:

We should be involved in everything they do in the welding shop. Not only the bosses should decide. We didn't want the new welding curtains, because they are too dark. They've hung them up anyway. The bosses decide - we are not involved.

In terms of question 1, there were no significant differences between Company 1 and Company 2 employees, but what about between typical and atypical workers?

Table 2: $\quad$ Interpretations of answers to question 1

\begin{tabular}{|l|c|c|}
\hline Commitment object & Typical workers & Atypical workers \\
\hline 1. Employer & $55 \%(12)$ & $44 \%(14)$ \\
\hline 2. Work & $27 \%(6)$ & $34 \%(11)$ \\
\hline 3. Colleagues & $18 \%(4)$ & $16 \%(5)$ \\
\hline 4. Department & $14 \%(3)$ & - \\
\hline 5. Organisation & $14 \%(3)$ & $13 \%(4)$ \\
\hline
\end{tabular}

Both typical and atypical workers primarily see commitment as employer commitment, followed by commitment towards their work and colleagues. In Table 2, there are only few notable differences between the groups: employees with a typical employment relationship more frequently mentioned employer, department, and work commitment. After a deeper analysis something quite stunning emerged: atypical workers are more likely to think that the organisation is committed to the employees $(28 \%$ as against $14 \%$ for typical workers); and typical workers are more likely to be dissatisfied with their employer's commitment (27\% as against $9 \%$ for atypical workers). It would seem that permanent employees have higher expectations of employer's commitment than non-permanent ones. From the former, we heard many complaints about their employers' involvement and this explains the disappointment noted by a significant 
number of typical workers. On the other hand, both the employers involved in the research seemed to exceed the expectations of their temporary workers. During the interviews and informal discussions on the shopfloor, many experienced atypical workers told us that, in contrast to other organisations they had worked for, these two companies treated them as equals in terms of employee influence. This was greatly appreciated:

They involve you, they motivate you to raise your finger, and share your opinion. Comparing to other companies, this is not normal.

The supervisors and managers (personnel manager, production managers) reported that both companies believe that good practices concerning atypical workers' influence trigger knowledge transfer which is valuable since many atypical workers build up extensive working experience at other companies. Later, when discussing the answers to questions $2-5$, it will be seen that there are non-discriminatory policies in other HRM areas at both companies.

Turning now to the differences in department commitment: these do not have anything to do with the contractual form, but can be explained by the duration of stay. It takes time to develop a commitment towards such an abstract object. This will be considered further when discussing the answers to question 4 (department commitment). In the next section we discuss work commitment profoundly.

\section{Question 2: What does commitment towards your daily work mean to you?}

From this question on, the focus is on the bases of commitment. Most answers were found to fit the initial mind-set. Only six men of the 54 challenged it: they saw themselves as the object of, rather than the subject of, work commitment. For them, it is about whether the organisation involves them in workplace-related ideas and changes. From the analysis, it has been concluded that differences between the companies and between typical and atypical workers concerning work commitment are minimal (see Table 3).

Table 3: Interpretations of basis of work commitment

\begin{tabular}{|l|c|c|c|}
\hline & Affective & Normative & Calculative \\
\hline Typical workers & $14 \%(3)$ & $77 \%(17)$ & - \\
\hline Atypical workers & $13 \%(4)$ & $69 \%(22)$ & $6 \%(2)$ \\
\hline
\end{tabular}

A minority of workers relate work commitment to enjoyment: maintaining the work because they like doing it. One of these affective answers is especially noteworthy: it is special because of the content and the fact that it is an atypical worker that expresses it. This man has a rather special employment relationship with Company 1 since his employer is an agrarian company that has a joint venture agreement with Company 1. The two companies involved have different seasonal peaks and, in order to save money and retain good, long-term atypical workers, two agrarian workers join the metal company for six months each year. Taking on workers with an agricultural background has a major advantage: with their education and experience they are able to fit and weld, and so the initial training period is short. The two workers involved have worked in this pattern for Company 1 for ten years. One of them said: 
The products I make here also have a place in my private life. In my leisure time I build these products as miniatures.

Four of the seven workers who relate work commitment to an emotional base, all of them atypical workers from Company 1, express the view that they do not like their work. This could lead to the conclusion that atypical workers in Company 1 have less affective commitment than typical workers. However, for two reasons, this would be a mistake. Firstly, from the above-mentioned quote it is clear that atypical workers can enjoy their work. Secondly, all the dissatisfied workers do the same kind of work: they are involved in the 'final welding' process. This means they weld large pieces of metal together in order to form a container. All welders characterise this so-called 'metre welding' as extremely boring and tiring, and none of the typical and long-term atypical workers do this work. However, it would be too simplistic to relate the job content to the employment relationship, with corresponding negative consequences for work commitment. First of all, all new workers join the companies through temporary work agencies. This is a recruitment and selection policy in both companies. Secondly, all new workers start with comparatively simple tasks regardless of their employment relationship. The final welding process is one such task, and all the 'final welders' had worked for less than six months for company 1. Thus, the job content depends on the duration of stay rather than the contract type. This was evidenced by the fact that atypical workers with a service record do the same work as their colleagues with a typical contract. Another observation that can be shared concerning equal job content relates to the cleaning of an oil tank. This very dirty job has to be repeated every few weeks. While walking past two men busy with this activity they called out jokingly "This should be a temp worker's job". Both had typical contracts.

It is very important to stress, and not only in this context, that both companies strive for long-term relationships with atypical workers. Neither company hires workers for just a number of days or a few weeks. Their peak seasons last six months, and so the stay of atypical workers covers at least this period. Furthermore, 'good' agency workers have a real chance of gaining an employment relationship with the company or at least of getting hired on a regular basis every year for the seasonal peak (such as the agrarian workers).

Table 3 shows that only two atypical workers relate work commitment to a costbenefit analysis, and more specifically to a lack of alternatives:

What do you mean by 'commitment'? From what else could I make my living?

The two workers have something in common which is more significant than their employment relationship (temping contract and less than six months service) and the fact that they work for Company 2: both have a lack of appropriate vocational training. One received a retail business education but has no certificate; the other has vocational training as an electrician in his native country, and further his Dutch is very poor. With these deficiencies, they have very limited opportunities for better work either inside or outside the company. The men assist with the welding robot: the only task in either welding shop where no education or course certificates are required. All the other welding shop workers in Company 1 and Company 2 have the relevant certificates. 
Both typical and atypical workers generally interpreted work commitment as a normative affair. Three examples of normative quotes are:

Doing your work according to your own rules and those of your boss.

I don't like it if I make mistakes.

I take responsibility for what I am doing, not being work-shy. That's the way I am and that has also something to do with the way I was brought up. I want people to be satisfied with me and not negative. I want there to be a positive understanding between other people and me.

It is not surprising that the workers mostly relate work commitment to norms. Even if you do not like your work much, you have to perform well in order to avoid negative consequences such as a bad conscience, annoyed co-workers (seen as a sponger), or dismissal. A more profound look at the workers' sayings revealed one difference between typical and atypical workers concerning normative work commitment: relatively more typical than atypical workers saw themselves as 'good' in terms of normative commitment towards work (73\% against 59\%). The atypical workers attribute this to the fact that they do the less exciting work. As mentioned earlier, and supported by the temporary workers themselves, this has nothing to do with their employment relationship, but with the duration of stay. Again, the final welders responded in a negative way:

I am not as committed as in the beginning. Everything you do for a long period of time, you do easily and therefore you'll be less committed. During the first few bins you're committed, later on it's routine and you're not longer committed. In the beginning you try to do everything perfectly, then you're committed. Now I am more relaxed. For example, look at the welding spatters. At the beginning you remove every spatter. Now you don't.

Having listened to all the workers carefully, the overall outcomes concerning work commitment were not surprising. Only a few workers expressed affective commitment towards their work, and almost 30 per cent of typical and 40 per cent of atypical workers confessed to a lack of normative commitment. According to the workers, the task content, mobility policies, and their poor influence over their mobility (an 'employers commitment' interpretation) are responsible. Many workers want job improvement: they desire more challenge and variety. They relate their low work commitment directly to work system policies. It is notable that, in both companies, welders are less satisfied with their work than fitters. The welders themselves relate this to their position in the production process - they 'only' manufacture pieces of the final product - and they have heavier physical work conditions. Mobility policies are criticised by both welders and fitters. Many workers had expressed the desire "to do something else" to their direct supervisors. However, the process from request to response took a long time. From conversations with supervisors and the personnel manager, it was found that they supported the worker's view; and they attributed this shortcoming to the labour market situation: at that time it was extremely hard to find competent workers and especially welders. Therefore, finding replacement personnel was almost impossible (Production Manager's words: “... filling holes with holes.”). In both companies, atypical workers had equal opportunities for mobility: one of the welders with a temporary contract (five years of service) moved from the welding 
shop to the drawing office, and two others (with six-months of service) were paid to attend a course by the hiring-in company.

The buoyant Dutch labour market situation in this period could also explains why there were so few calculative, lack of alternatives, interpretations. The metalworkers perceived a low alignment with their work: according to them, changing jobs - even to non-technical ones - was relatively easy. However, from another viewpoint, the infrequency of the low alternative response is surprising given the criticism of the mobility policies and that, according to the workers and their supervisors, the opportunities for intra-organisational mobility are limited. None of the workers connected work commitment to 'high sacrifices'. Two explanations are offered: 1) the workers simply do not relate 'commitment' to sacrifices, or 2) the metalworkers have little to loose. Such arguments can also apply to 'alternatives' and commitment in general.

\section{Question 3: What does commitment towards your colleagues mean to you?}

Again, the similarities between the companies and between typical and atypical workers are more striking than the differences:

Table 4: Interpretations of commitment to colleagues

\begin{tabular}{|l|c|c|c|}
\hline & Affective & Normative & Calculative \\
\hline Typical workers & $82 \%(18)$ & $32 \%(7)$ & $9 \%(3)$ \\
\hline Atypical workers & $91 \%(29)$ & $50 \%(16)$ & $14 \%(3)$ \\
\hline
\end{tabular}

Most workers link colleague commitment to affection: somebody with affective colleague commitment has positive emotions towards his workmates. Examples are "I have nice colleagues" and "My co-workers are like a family". Atypical workers were slightly more likely to express affective commitment towards colleagues than typical workers. One somewhat provocative suggestion is that it is possible that the duration of the relationship has an effect: as in partner relationships, after a time one perceives ones colleagues more realistically: it takes some time to discover the small, or not so small, shortcomings. Since atypical workers in general have a shorter record of service than typical workers, this argument may be valid.

The majority of typical and atypical workers relate colleague commitment to 'things you should and shouldn't do as a colleague'. Whereas affective colleague commitment has to do with the person, irrespective of the job, normative commitment is about the 'colleague on duty'. According to the workers, colleagues who behave in a supportive and helpful way are normatively committed: they 'show' fellowship. Most men expressing normative commitment perceive themselves as good colleagues (21 of 23). Sometimes the norm is quite explicitly put (for example: "being straightforward and not sneaky"), other times it is less clear:

I want to see if everybody performs the tasks they have to do. I keep an eye on my colleagues, I watch them. One colleague of mine was very late every morning for approximately two years. He always had excuses for his late appearance and he was a difficult person to deal with. At that time, I said to myself: I will buy him an alarm clock, but finally I didn't do it. I am still committed towards this colleague. 
This man (with a typical contract) appears to check if his colleagues obey (organisational) norms: he acts as a norm-keeper. Table 4 reveals that more atypical than typical workers link colleague commitment to norms. Asked about the strength of their normative commitment, more atypical than typical workers expressed a good level of collegiality. How can one explain these differences? Perhaps one should not be surprised: all new workers have to rely on older incumbents to find their way through the company. Therefore, newcomers will depend more on colleagues for back up. Thus, not the employment relationship but the record of service is responsible. The workers' responses support this conclusion in that: 1) it is mainly short-term atypical workers that associate colleagues with the above-mentioned behaviours, and 2) they relate this because of their relative unfamiliarity with the company. This is a good example of the relationship between normative and calculative commitments (Meyer et al. 1993). A minority of workers, with no appreciable differences between typical and atypical workers, associated colleague commitment 'directly' with calculation and more specifically with 'few alternatives': in order to get their work done, they have to rely on their workmates. One typical worker explains:

For building this machine I have to cooperate with colleagues. To get the machine parts, (name of colleague) is responsible for the pieces I need, that's mostly why I'm committed towards him. I have the most commitment towards (name of the colleague) because I need him.

The limited number of calculative answers is attributed to the same reasons as given above for 'work commitment'. A final observation is that, for this focus of commitment, not a single 'employers commitment' interpretation was given.

\section{Question 4: What does commitment towards your department mean to you?}

Many workers (20 out of 54 men or 37\%) could not provide an answer to this question. For others, colleague and department commitment are the same, and they referred to their colleague commitment answer. However, the department is a more global concept: a department consists not only of colleagues but also of supervisors and department-specific products. The 'employer commitment' answers had been fairly common among the various groups. However, in terms of the workers involvement in department affairs, there was a spectacular difference between the typical and atypical workers.

Table 5: Interpretations of commitment to the department

\begin{tabular}{|l|c|c|c|}
\hline & Affective & Normative & Calculative \\
\hline Typical workers & $18 \%(4)$ & $64 \%(14)$ & $5 \%(1)$ \\
\hline Atypical workers & $22 \%(7)$ & $31 \%(10)$ & $3 \%(1)$ \\
\hline
\end{tabular}

The department focus revealed the largest differences between typical and atypical workers in the whole study. The largest distinction, which is not obvious from Table 5 , has to do with a non-response: 17 of the $20(85 \%)$ non-responders were atypical workers, in other words 53 per cent of this group were unable to connect the department to commitment. The other significant finding is the importance of normative 
commitment: both groups linked department commitment primarily to norms and values - they feel responsible for departmental affairs:

If I hear that my department makes mistakes, I feel responsible. Or you strive for the same, you strive for a good product.

Significantly, many more typical rather than atypical workers put such an interpretation on their commitment. Furthermore, more typical workers think that their departmental commitment is at an appropriate level (50\% compared with 19\%). How can one explain these outcomes? Does the employment relationship really matter? The workers do not think so. More than half of the atypical non-response cases attributed their lack of a response to their short record of service, and indeed all of them had been there for less than six months. In other words: the duration of stay again influences the relationship between employment and commitment. Thus, an employer will only 'suffer' in the short-term from low department commitment by atypical workers. The department is clearly a more abstract concept than work and colleagues, and therefore it takes longer for a worker to know what constitutes part of his department: a vital condition for developing any commitment.

All the other differences are not very significant. To summarise, only a few workers linked department commitment to affective and calculative motives. In terms of the former, they relate this focus of commitment to emotional attachment ("I feel at home in this welding shop"); with regard to the latter, to dependencies and, more specifically, again to a lack of alternatives ("I would like to work for another department, but they need people here"). After a more in-depth look, from the workers' point of view, one has to conclude that the following circumstances caused these outcomes. One of the possible causes of low department mobility has already been discussed: the tight labour market. In both companies, welders were more disappointed than fitters with the lack of mobility opportunities. What seems very apparent is the welders' desires for decent treatment and employee influence: they are less satisfied than the fitters with their current situation. In both welding shops, in comparison with the assembly areas, the men complain much more about their supervisors' management skills during daily contacts and department meetings. In terms of the former, the welders perceived a lack of social skills and therefore also doubted the leadership competencies. Both factors resulted in frustrating and/or turbulent group meetings with one-sided top-down information flows. In Company 2, one of the supervisors and his subordinates were observed haranguing each other during a meeting: one welder (on a typical contract) left the meeting and told his boss to bugger off. It should also be mentioned that, from the time spent at Company 2, it was found that the department layout matters. Here, three workers work with the welding robot and all of them are temporary workers, two of them, as mentioned earlier, having no suitable education for other jobs. This robot is placed approximately 20 metres away from where the other welders work manually, and the robot 'servants' blame their low welding shop commitment on this physical distance.

\section{Question 5: What does commitment towards (name of the company) mean to you?}

It was decided to use the name of the company rather than the more abstract concept of "organisation" since when talking to workers on the shopfloor it quickly became 
clear that this concept was somewhat irrational to the metalworkers. If the term 'the organisation' was used without mentioning the company's name then many responses were along the lines of "I have nothing to do with organising, the bosses and clerks do that". Once the question was clear, the typical and atypical workers reacted in similar ways.

Table 6: Interpretations of commitment towards the company

\begin{tabular}{|l|c|c|c|}
\hline & Affective & Normative & Calculative \\
\hline Typical workers & $23 \%(5)$ & $23 \%(5)$ & $5 \%(1)$ \\
\hline Atypical workers & $31 \%(10)$ & $25 \%(8)$ & $34 \%(11)$ \\
\hline
\end{tabular}

Looking at Table 6, one has to again conclude that the similarities are more striking than the differences: with one exception - in comparison to other foci, calculative commitment seems important for atypical workers. Again, the lack of an alternative was a commonly expressed explanation for this form of commitment but for this focus, unlike the others, the worker's also expressed 'high sacrifices' as a reason:

Here, I know everything and everybody. It would take a long time to achieve this at another company.

Initially, Table 6 seems to support a commonly held assumption on the contract and commitment relationship: that calculative organisational commitment appears to be more important for atypical workers. Many researchers have emphasised that atypical work is a 'second choice alternative': people work under such conditions because of a lack of alternatives. Indeed, here, 6 of the 11 atypical workers stressed their lack of alternatives in the external labour market. These six had similar causes of their lack of alternatives: their poor Dutch and/or training. The remaining 5 of the 11 atypical workers who base their company commitment on a cost-benefit analysis emphasise their good position in the labour market. All of them had undergone long-term occupational training and actively chose to work on a temporary basis. One of them (with a wife without paid work and two children) even terminated his permanent contract to join 'the flexible workforce'. He said:

I had enough of my colleagues and my permanent job. As a temp worker you have a better choice between different employers. You can tell the agency if you don't like a job, and they look for something else. Temp agencies are a perfect institution if you want work. The [government] employment office is no good for anything. They do nothing. I was registered for two or three years and never got a job offer, but when I had received unemployment benefits for three weeks they called. Temp agencies can help you to find a job immediately.

Something else was perhaps surprising: all of them were primary or secondary 'victims' of redundancies - they had personally been dismissed or had witnessed colleagues struck by this fate. From these experiences they had learnt that even a permanent contract did not guarantee job and financial security ("If the boss wants or has to get rid of you, he will"). It seems that, for this group of workers, as a result of their experiences with layoffs and temping work, that job or contract security is of low importance: they had refused a permanent contract with the company. Something else is obvious. All of them worked for company 1 and complaint about the permanent 
workers' low salary. Another reason to stay with the agency. In contrast, company 2 agency workers earned significantly less than typical workers: approximately 200 Euro net.

Relatively few workers associate company commitment with their own affection ("I really like this company") and norms:

If they need me, for example for overtime, I do it for the business and myself. (Name of the company) treats me well, that's why I want to return something. All questions about commitment deal with honesty.

The workers blame the same conditions as they referred to over department commitment for their limited affective and normative organisational commitments: 1) the record of service ("old employees are committed to the company"), 2) their hierarchical position, and 3) a lack of employer commitment towards the workers. In terms of the last point, a new 'dimension' was uncovered at Company 1. Permanent employees were extremely dissatisfied with their performance interviews: the supervisors were not adequately prepared for this task. As a result, serious mistakes were made and vividly remembered by the employees. The interviews were not a two-sided, 'democratic' conversation, with attention given to both supervisors' and workers' performance, but a one-sided assessment interview. The workers attributed their reduced organisational commitment directly to this course of events. For atypical workers, there was another critical organisational behaviour that decreased their affective and normative commitment: both companies failed to keep contract promises. For example, Company 2 had initially promised one temp worker a company contract. After about six-months he saw company vacancies advertised in a newspaper offering non-permanent contracts. He was furious because nobody had told him about the job openings, and the fact that 'newer' workers would get a better employment relationship than he had. In his own words, this incident proved fatal for his company commitment, and he left the company two months later.

Many workers (28 of 54) also expressed 'employer commitment':

They tell us about events and changes in daily routine. For example about the backlog of orders, as things stand; and about the new building and that we can participate.

Recently, they involved me in the design of the new building for the welding shop. I liked that.

21 of the 28 expressed the view that they want the organisation to be more committed. As earlier, the typical workers were the more dissatisfied with their treatment and employee influence.

\section{Conclusion}

There is some evidence from these results that not only employment relationship policies but all HRM policies are significant for the commitment of atypical workers. In other words, HRM policies for atypical workers do not start and end with contract policies. (1) Since the similarities between typical and atypical workers in this study are more striking than the differences, it would appear that job security is less important for employee commitment than many have claimed. What then are the implications of this study for HR policies in terms of simultaneously maintaining flexible working practices and commitment? (2) One successful approach would seem to be through 
the HR policies for flexible workers adopted in the case study companies: equal treatment policies, and after a successful initial period, taking a long term perspective.

(3) Companies have other, maybe less obvious, opportunities to establish longterm relationships with flexible workers and so encourage commitment, such as the successful co-operation between Company 1 and an agrarian employer discussed earlier. This is just one example of innovative staffing policies that could enable employers to create commitment-inducing long-term relationships with flexible workers. In this sense, companies should be creative entrepreneurs.

(4) The companies studied attempted to meet the HRM aspirations of their flexible workers, and to minimise the differences between them and typical workers, through adopting equal treatment policies. In general, only if HRM meets the expectations of employees can employers expect their workers to show commitment. Regarding policy choices that affect them personally, all workers want managers and supervisors to listen to their views. HRM must provide space for each individual and use a range of appropriate approaches since preferences do differ, among both permanent and flexible workers. This requires an increase in HR management activity: the needs of the company and of all of its workers need to be mapped, and matched as far as possible.

(5) Direct supervisors can play a major part in realising this since they are the most familiar with their staff and therefore best able to establish employee profiles. Effective job and performance interviews are helpful instruments in gaining the necessary information. This argument explains why differentiated HR policies require an appropriately developed middle management. Companies should give particular attention to atypical workers who are not in this situation by choice. In terms of staffing policies for such workers, managers need to realise that even vague contractual promises generate high worker expectations. Psychological violation will occur, leading to declining commitment and related outcomes such as staff turnover, if managers fail to keep these promises.

(6) In terms of staffing policies, educational facilities, and rewards; contracttriangles are extremely challenging. A hiring-in company is able to actively influence the HR policies of the company that formally employs the workers. In other words, companies should keep an eye on temping agencies - and never completely outsource HR policies - since their practices can affect workers' attitudes and behaviours. In this case study, the personnel manager (responsible for both companies) influenced the staffing policy of the temp agencies: if the companies were satisfied with a particular worker the personnel manager insisted that the agency offered a tighter employment relationship. The temp workers appreciated this influence, and the companies benefited in return through increased commitment and positive behaviour. The personnel manager also emphasised that a solid relationship between the hiring-in and loaningout companies was not only beneficial for the negotiating position of the former, but also for the quality of the flexible workforce provided. Long-term contacts enable them to acquire top quality workers. In view of these outcomes, one can conclude that the employment relationship does not necessarily determine employee commitment: much depends on the attitude of the hiring company. 


\section{References}

Allegro, J./Breukelen, W. van (2000): Effecten van een nieuwe vorm van flexibilisering van de arbeid. In: Gedrag en Organisatie, 13(2): 107-124.

Allen, N.J./Meyer, J.P. (1990): The measurement and antecedents of affective, continuance and normative commitment to the organization. In: Journal of Occupational Psychology, 63: 1-18.

Atkinson, J./Meager, N. (1986): New forms of work organisation. IMS Report No. 121. Brighton: Institute of Manpower Studies.

Baruch, Y. (1998): The rise and fall of organizational commitment. In: Human Systems Management, 17(2): 135-144.

Beck, K./Wilson, C. (2001): Have we studied, should we study, and can we study the development of commitment? Methodological issues and the developmental study of work-related commitment. In: Human Resource Management Review, 11(3): 257-278.

Becker, T.E./Billings, R.S. (1993): Profiles of commitment: an empirical test', Journal of Organizational Behavior, 14: 177-190.

Becker, T.E./Billings, R.S./Eveleth, D.M./Gilbert, N.L. (1996): Foci and bases of employee commitment: implications for job performance. In: Academy of Management Journal, 39(2): 464-482.

Beer, M./Spector, B./Lawrence, P.R./Quinn Mills, D./Walton, R.E. (1984): Managing Human Assets. New York: The Free Press.

Blumer, H. (1954): What is wrong with social theory? In: American Sociological Review, 19: 3-10.

CIETT (2000): Orchestrating the evolution of private employment agencies towards a stronger society. Brussels: CIET'T (www.ciett.org).

Coopey, J./Hartley, J. (1993): Reconsidering the case for organisational commitment. In: Human Resource Management Journal, 1(3): 18-32.

Coopey, J. (1995): Managerial culture and the stillbirth of organisational commitment. In: Human Resource Management Journal, 5(3): 56-76.

Douglas, J.D. (1976): Investigative social research: individual and team field research. London: Sage Publications.

Dyne, L. van/Ang, S. (1998) Organizational citizenship behaviour of contingent workers in Singapore. In: Academy of Management Journal, 41(6): 692-703.

Gallagher, D.G./Sverke, M. (2000): Contingent employment contracts: are existing employment theories still relevant. Paper, $12^{\text {th }}$ world-conference IIRA, Tokyo, Japan.

Gallagher, D.G./McLean Parks, J. (2001): I pledge thee troth ... contingently: commitment and the contingent work relationship. In: Human Resource Management Review, 11(3): 181-208.

Gallie, D./White, M. (1993): Employee Commitment and the Skills Revolution. London: Policy Studies Institute.

Geary, J.F. (1992): Pay, control and commitment: linking appraisal and reward. In: Human Resource Management Journal, 2(4): 36-54.

Goudswaard, A./Andries, F. (2002): Employment status and working conditions. Dublin: European Foundation.

Guba, E.G./Lincoln, Y.S. (1982): Epistemological and methodological bases of naturalistic inquiries. In: Educational Communication and Technology Journal, 30: 233-252.

Guest, D.E. (1998): Beyond HRM: commitment and the contract culture. In: P. Sparrow/M. Marchington (Eds.): Human Resource Management: the new agenda. London: FT Pitman Publishing: 37-51.

Jacobsen, D.I. (2000): Managing increased part-time: does part-time work imply part-time commitment? In: Managing Service Quality, 10(3): 187-200.

Kessler, I./Coyle-Shapiro J./Purcell, J. (1999): Outsourcing and the employee perspective. In: Human Resource Management Journal, 9 (2): 5-19.

Mellor, S./Mathieu, J.E./Barnes-Farrell, J.L./Rogelberg, S.G. (2001): Employees' nonwork obligations and organizational commitments: a new way to look at the relationships. In: Human Resource Management, 40(2): 171-184. 
Meyer, J.P./Paunonen, S.V./Gellatly, I.R./Goffin, R.D./Jackson, D.M. (1989): Organizational commitment and job performance: it's the nature of the commitment that counts. In: Journal of Applied Psychology, 74(1): 152-156.

Meyer, J.P./Allen, N.J./Smith, C.A. (1993): Commitment to organizations and occupations: extension and test of a three-component conceptualisation. In: Journal of Applied Psychology, 78(4): 538-551.

Meyer, J.P./Herscovitch, L. (2001): Commitment in the workplace: toward a general model. In: Human Resource Management Review, 11(3): 299-236.

Millward, L.J./Hopkins, L.J. (1998): Psychological contracts, organizational and job commitment. In: Journal of Applied Social Psychology, 28(16): 1530-1556.

Morris, T./Lydka, H./O’Creevy, F. (1993): Can commitment be managed? A longitudinal analysis of employee commitment and human resource policies. In: Human Resource Management Journal, 3(3): 21-42.

Morrow, P.C./McElroy, J.C. (2001): Work commitment: conceptual and methodological developments for the management of human resources. In: Human Resource Management Review, 11(3): 177180.

Pearce, J.L. (1993): Toward an organizational behavior of contract laborers: their psychological involvement and effect on co-workers. In: Academy of Management Journal, 36 (5): 1082-1096.

Porter, L.W./Steers, R.M./Mowday, R.T./Boulian, P.V. (1974): Organizational commitment, job satisfaction, and turnover among psychiatric technicians. In: Journal of Applied Psychology, 59: 603-609.

Purcell, K./Purcell, J. (1998): In-sourcing, outsourcing, and the growth of contingent labour as evidence of flexible employment strategies. In: The European Journal of Work and Organizational Psychology, 7(1): 39-60.

Randall, D.M./Fedor, D.B./Longenecker, C.O. (1990): The behavioral expression of organizational commitment. In: Journal of Vocational Behavior, 36: 210-224.

Randstad 2004. Jaarverslag (2003): http://www.nl.randstad.com/holding/investor-relations/financial-reports.xml

Reichers, A.E. (1985): A review and reconceptualization of organizational commitment. In: Academy of Management Review, 10: 465-476.

Rousseau, D.M. (1995): Psychological Contracts in Organizations: understanding written and un-written agreements. Newbury Park, CA: Sage Publications.

Shore, L.M./Martin, H.J. (1989): Job satisfaction and organizational commitment in relation to work performance and turnover intentions. In: Human Relations, 42(7): 625-638.

Singh, V./Vinnicombe, S. (2000): What does commitment really mean: views of UK and Swedish engineering managers. In: Personnel Review, 29(2): 228-254.

Steijn, B. (2000): Work-systems, quality of labour, and attitudes of workers. An empirical study towards the effects of team and non-team work. Paper, Rotterdam/NL, Erasmus University of Rotterdam.

Welsch, H.P./LaVan, H. (1981): Inter-relationships between organizational commitment and job characteristics, job satisfaction, professional behaviour, and organizational climate. In: Human Relations, 34(12): 1079-1089.

Wiener, Y. (1982): Commitment in organizations: a normative view. In: Academy of Management Review, 7(3): 418-428.

Yoon, J./Baker, M.R./Ko, J.-W. (1994): Interpersonal attachment and organizational commitment: subgroup hypothesis revisited. In: Human Relations, 47(3): 329-351. 